\title{
Karakteristik Public Relation pada Departemen Marketing Public Relations CNN Indonesia TV
}

\author{
*Ayu Puspa Yurita ${ }^{1}$, Anwar Sani ${ }^{2}$ \\ ${ }^{1,2}$ Universitas Padjadjaran, \\ Bandung
}

\begin{abstract}
ABSTRAK
Banyaknya penggunaan nama pada divisi atau departemen public relations memberikan kesan bahwa tugas dan fungsi divisi atau departemen public relation di sebuah perusahaan kemudian berbeda dengan perusahaan lain. Perbedaan pada fungsi, tugas, peran, dan kegiatan yang dilakukan oleh divisi atau departemen public relations itu dapat menentukan karakteristik public relations pada perusahaan. Tujuan penelitian ini untuk mengetahui tujuan, fungsi, peran, juga aktivitas departemen marketing public relations di CNN Indonesia TV. Metode penelitian yang digunakan adalah deskriptif kualitatif. Hasil penelitian menjelaskan bahwa perbedaan tujuan, fungsi, dan peran tergantung dari kebijakan perusahaan masing- masing. CNN Indonesia TV melakukan efisiensi pada tujuan dan fungsi perusahaan, sedangkan peran departemen marketing public relations-nya sejalan dengan misi PR perusahaan yaitu ikut berkontribusi langsung dalam revenue perusahaan. Sedangkan aktivitas yang diinisiasi oleh CNN Indonesia ada 3, yaitu Dialog, Monolog, dan Meet Up. Dari 3 poin pada pembahasaan tersebut akhirnya dapat diketahui seperti apa karakteristik public relations pada departemen marketing public relations CNN Indonesia TV.
\end{abstract}

Kata Kunci: Media Massa; Karakteristik; Public Relations; Marketing Public Relations; Fungsi

\begin{abstract}
The many uses of names in the division or department of public relations that give the impression that the tasks and functions of the division or department are not the same as at first. Differences in functions, tasks, roles, and activities carried out by the division or public relations department can determine public relations in company. This the background of the writer will describe characteristics of public relations in the public relations marketing departement CNN Indonesia TV. The purpose of this study was to determine the objectives, functions, roles, and also the marketing business relations department at CNN Indonesia TV. The research method is descriptive qualitative. The results of the study explain that the number of goals, functions, and roles depends on each company. CNN Indonesia TV transfers the functions and functions of the company, while the marketing office relations of public relations are within the mission of the company's public relations incorporated in the company's revenue. While the activities initiated by CNN Indonesia are 3, namely Dialogue, Monologue, and Meet Up. Of the 3 points in the discussion, it can finally be seen as what public relations in the CNN Indonesia TV marketing public relations department.
\end{abstract}


Keywords: Mass Media; Characteristics; Public Relations; Marketing Public Relations; Function

*Korespondensi: Ayu Puspa Yurita. Program Studi Public Relations Universitas Padjadjaran. Jl. Raya Bandung Sumedang KM.21, Hegarmanah, Jatinangor, Kabupaten Sumedang, Jawa Barat 45363.Email: ayupus585@gmail.com

\section{PENDAHULUAN}

Media massa adalah salah satu alat yang digunakan dalam menyampaikan pesan kepada khalayak dengan menggunakan alat-alat komunikasi seperti televisi, radio, surat kabar dan lain lain. Dewasa ini, seiring berkembangnya teknologi, media massa pun turut berkembang mengikuti zaman. Salah satunya adalah media konvensional atau media cetak dan munculnya istilah baru yaitu 'New Media' atau media baru.

Media konvensional atau media cetak merupakan media yang terbit terus menerus dengan bentuk tulisan yang mengandung unsur $5 \mathrm{~W}+1 \mathrm{H}$ serta media cetak memiliki audiens yang terbatas. Berita pada media konvensional disajikan dalam bentuk seperti surat kabar, artikel tajuk dan lain-lain. Media konvensional seperti surat kabar dalam menyampaikan berita sangat dipengaruhi oleh orang-orang yang berada di dalam media itu sendiri seperti wartawan, penulis editor, pimpinan serta redaksi, dan berhasilnya sebuah perusahaan tentu tidak lepas dari peran public relations dalam membentuk citra perusahaan.

Public Relations adalah suatu proses komunikasi yang terencana guna membangun hubungan antara publik dan organisasinya. Komunikasi merupakan modal utama yang harus dimiliki oleh Public Relations dalam membangun hubungan antara organisasi dan publiknya. Setiap program Public Relations yang dikomunikasikan kepada publiknya haruslah membangun image atau citra dari organisasi tersebut. Public Relations juga harus selalu menjaga agar citra organisasinya tetap baik ketika dalam permasalahan maupun sedang tidak dalam permasalahan Public Relations harus menjaga agar organisasinya dalam keadaan baik. Pesatnya perkembangan profesi Public Relations dewasa ini terlihat dengan makin banyaknya organisasi atau lembaga yang membentuk unit khusus Public Relations khususnya dalam perusahaan penyedia layanan informasi salah satunya untuk menjalankan fungsi Marketing Public Relations.

Definisi Marketing Public Relations itu sendiri adalah proses perencanaan, pelaksanaan dan evaluasi program yang mendorong pembelian dan kepuasan konsumen melalui komunikasi informasi dan tayangan yang kredibel yang mengidentifikasi perusahaan dan produk mereka dengan kebutuhan, keinginan, perhatian, dan kepentingan konsumen. Fungsi dan peran serta Marketing Public Relations sebagai garda depan sekaligus backup bagi perusahaan memiliki peran penting untuk menjaga citra produk (brand image product) dan citra perusahaan (corporate image) terhadap publik, yang salah satunya adalah pelanggan. Salah satu cara jangka panjang yang dapat dilakukan perusahaan dalam mempertahankan eksistensinya adalah dengan 
membangun kesetiaan pelanggan.

Seperti peran Public Relations didalam perusahaan yang bergerak dibidang media televisi yaitu Cable News Network Indonesia (CNN Indonesia). CNN Indonesia merupakan stasiun televisi dan situs berita milik Trans Media bekerjasama dengan Turner International. CNN Indonesia memulai kemunculannya melalui portal berita CNNIndonesia.com diikuti dengan kehadiran CNN Indonesia TV pada 17 Agustus 2015. Sebagai bagian dari CNN International, CNN Indonesia diharapkan hadir sebagai jendela ke dunia untuk melihat Indonesia dan mata Indonesia untuk melihat dunia. CNN Indonesia mempersembahkan kepada masyarakat Indonesia yang menginginkan kualitas dan objektivitas untuk berita nasional dan internasional.

Melihat peran penting seorang praktisi public relations ternyata tidak demikian di beberapa perusahaan. Banyaknya penggunaan nama pada divisi atau departemen public relations memberikan kesan bahwa tugas dan fungsi divisi atau departemen tersebut tidak sama seperti pada mulanya. Pergantian pada nama public relations itu sendiri memberikan penambahan atau bahkan pengurangan dari tugas dan fungsi divisi atau departemen tersebut. Melihat perkembangan pada permasalahan tersebut sama hal nya yang di alami oleh CNN Indonesia TV. Peran public relations pada CNN Indonesia TV dipegang oleh departemen marketing public relations dimana di bawahi business strategic division.

Perbedaan pada fungsi, tugas, peran, dan kegiatan yang dilakukan oleh divisi atau departemen public relations itu dapat menentukan karakteristik public relations pada perusahaan. Hal inilah yang melatarbelakangi penulis akan menguraikan karakteristik public relations pada departemen marketing public relations CNN Indonesia TV. Karakteristik pada departemen marketing public relations CNN Indonesia TV ini akan diuraikan dalam Laporan Job Training mulai dari penjelasan mengenai tujuan, fungsi, peran, dan kegiatan yang dilakukan sehingga terdapat departemen marketing public relations di CNN Indonesia TV. Serta akan diuraikan juga bagaimana Marketing Public Relations Departement CNN Indonesia TV menanggapi dan menghadapi fenomena yang terjadi mengenai hadirnya new media. Adapun tujuan pada penelitian ini yaitu (1) Untuk mengetahui tujuan dan fungsi Marketing Public Relations Departement pada CNN Indonesia TV, (2) Untuk mengetahui peran Marketing Public Relations Departement pada CNN Indonesia TV, (3) Untuk mengetahui aktivitas Marketing Public Relations Departement pada CNN Indonesia TV.

\section{METODE PENELITIAN}

Metode penulisan yang digunakan peneliti ini adalah metode deskriptif. Metode ini memungkinkanpenulis untuk dapat bebas mengamati objeknya, menjelajah, dan enemukan wawasan-wawasan baru sepanjang penelitian (Ardianto,2011, hal 118). Hal ini berkaitan dengan penguraian pengalaman peneliti setelah terjun langsung dalam mengikuti kegiatan Job Training di CNN Indonesia TV. Jenis penelitian ini adalah kualiatatif. Objek pada penelitian ini adalah Departemen Marketing Public Relations CNN Indonesia TV. Teknik pengumpulan data pada proses penelitian ini adalah pembelajaran proaktif sambilmengamati dan mengikuti beberapa kegiatan yang 
berkaitan dengan aktifitas Public Relations. Adapun teknik-teknik yang digunakan peneliti dalam pengumpulan data yaitu observasi, wawancara, dokumen, juga praktik langsung. Adapun lokasi pelaksanaan penelitian ini di laksanakan di PT Trans Media Corpora, Gedung Transmedia 1t.3 Jl. Kapten P. Tendean Kav. 12-14 A Mampang Prapatan, Jakarta Selatan 12790. Yang dilakukan selama 66 hari kerja terhitung sejak tanggal 4 Juli 2018 hingga 4 Oktober 2018.

\section{HASIL DAN PEMBAHASAN}

Pada awalnya, investasi CNN Indonesia berawal dari CNN Indonesia.com, dimana Trans Media pada saat itu merupakan unit bisnis baru. Maka fokus investasi CNNIndonesia.com lebih kepada bisnis. Bisnis inti yang dimaksud adalah bisnis yang langsung berhubungan dengan apa yang menjadi jualan sebuah perusahaan. Dalam hal ini CNNIndonesia.com, maka yang dijual itu adalah sebuah berita yang digitalkan atau sebuah teks. Oleh karena itu, investasi yang paling besar adalah ke bagian editorial, infrastruktur, IT, dan lain-lain. Fungsi- fungsi lainnya yang tidak berhubungan langsung kepada bisnis inti di Trans Media itu ada istilah manajemen yang sangat spesial disebut mirroring.

Mirroring atau cermin itu dilakukan oleh CNN Indonesia TV khususnya bagian Marketing Public Relations CNN Indonesia TV guna memperdayakan satu orang namun satu orang tersebut dapat dan mampu mengerjakan 2 sampai 3 pekerjaan sekaligus atau multitasking. Tujuannya adalah efisiensi, kalau 1 orang tersebut dapat diberdayakan untuk 2 sampai 3 pekerjaan, pihak MPR CNN Indonesia TV tidak perlu mempekerjakan banyak orang, namun tinggal bagian departemennya yang dipisah.

Yang terjadi dulu seperti itu, untuk infrastruktur, editorial, IT itu yang menjadi fokus investasi perusahaan. Fungsi- fungsi lain yang tidak berhubungan dengan bisnis inti seperti HR, finance, sales marketing, juga termasuk didalamnya marketing public relations itu tidak berhubungan secara langsung dengan bisnis inti. Oleh karena itu, dilakukan mirroring system ke organisasi- organisasi yang lebih mature atau yang lebih dulu ada. Maka beberapa fungsi departemen di mirroring ke detik, misalnya bagian finance, infrastruktur, HR. sedangkan bagian sales marketing, public relations itu di mirroring ke Trans TV.

Entitas perusahaan CNNIndonesia.com katakanlah masuk ke perusahaan detik, bisnis intinya ada IT, infrastruktur dan editorial. Kedua bisnis intinya, yang menjadi support itu bagian HR detik, PR, finance, sales marketing itu tidak menjadi fokus disitu. Jadi ada dua sudut pandang pertama dengan inovasi manajemen mirroring yang menjadi efisiensi dari segi biaya. Kalau seseorang ingin mendirikan sebuah perusahaan melihat dari portfolionya. Seberapa cepat perusahaan tersebut bisa membuat buku perusahan tersebut berwarna hijau atau seberapa cepat perusahaan tersebut bisa menjadi perusahaan yang untung. Semakin perusahaan tersebut menerapkan sistem efisiensi, maka semakin cepat perusahaan tersebut meraih keuntungan. Hal itu disebut dengan sisi makro.

Sedangkan dari sisi mikronya adalah, menurut Om Fred selaku kepala departemen MPR CNN Indonesia TV, treatment pada perusahaan besar sama dengan perusahaan yang kecil yang sebenarnya memiliki kebutuhan yang berbeda. Trans 
Media mempunyai market atau pasar yang besar, sedangkan untuk CNN Indonesia TV memiliki market atau pasar upper atau ditujukan untuk kelas atas kualitas dan lainlainnya. Otomatis pekerjaan seorang Public Relations, visi Public Relations itu tidak bisa dijalankan bersamaan. Artinya dia akan membuat program Public Relations yang sama, padahal mereka mempunyai target yang berbeda. Dan itulah yang terjadi pada CNN Indonesia TV.

Marketing Public Relatios pada prinsipnya adalah merupakan suatu kegiatan yang terencana dan suatu usaha yang terus menerus untuk dapat memantapkan dan mengembangan itikad baik (good will) dan pengertian yang timbal balik (mutual understanding) antara suatu organisasi dengan masyarakat. Secara garis besar peran MPR CNN Indonesia TV sama, namun orientasinya saja yang berbeda. Peran MPR CNN Indonesia TV adalah mendapatkan keuntungan sebesar-besarnya di setiap kegiatan yang dilaksanakan dan pada akhirnya dapat berdiri sendiri untuk memenuhi kebutuhan Marketing PR di CNN Indonesia TV.

Melihat ada dua aktivitas MPR CNN Indonesia TV yaitu partnership specialist dan event specialist membuat pekerjaan yang dilakukan oleh MPR CNN Indonesia TV terlihat sangat mudah, namun pada kenyataanya, dikarenakan CNN Indonesia khususnya departemen MPR nya menerapkan efisiensi para pekerja, maka akan terasa lebih melelahkan dalam melaksanakan sebuah kegiatan. Namun biaya yang dikeluarkan tidak terlalu besar. Marketing Public Relations (MPR) CNN Indonesia penekanannya bukan pada selling (seperti pada kegiatan periklanan), namun peran pemberian informasi, wawasan melalui program off air atau on air yang CNN Indonesia buat guna mendapatkan keuntungan berupa uang.

Media relations, community relations, publicity and merchandising itu dilebur menjadi 2 poin. Fungsi-fungsi yang tadi lebur dalam organisasi yang lebih ramping. Misalnya secretariat surat menyurat, MoU, pengadaan dan pertanggungjawaban merchandise, maintance database event itu di lakukan oleh sekretaris. Partnership semua yag sifatnya partner dengan pihak luar, visit, media partner, media relations itu akan di handle oleh partnership. Fungsi media relations tidak terlalu penting bagi CNN Indonesia TV karena CNN merupakan organisasi atau perusahaan media. Jadi kalau terjadi krisis yang akan pertama keluar adalah pimpinan redaksi bukan PR. Karena PR nya CNN Indonesia itu di layar. Misal terjadi krisi bahwa CNN Indonesia memberitakan berita hoax, nanti yang akan di cari oleh dewan pers itu adalah pimpinan redaksinya. Tapi kalau perusahaan lain khususnya pemerintahan, PR nya yang akan di cari oleh para media. Pada dasarnya, suara seorang Public Relations itu akan dianggap oleh media sebagai suara pemolesan citra. Seorang praktisi PR di CNN Indonesia akan melakukan klarifikasi dari sisi perusahaan, namun yang keluar dan menghadapi para media adalah pimpinan redaksi.

Tujuan dan fungsi PR Trans TV untuk menggarap tujuan dan fungsi PR CNNIndonesia.com itu yang dilakukan oleh Mas Adi. PR Trans TV itu lebih ke awareness program, jadi lebih mencari lokomotif program. Lokomotif itu adalah program yag menggerek channel seluruh program, dimana digerek oleh 1 atau 2 lokomotif program. Seperti program extravaganza, YKS, dan lain-lain. Yang mereka lakukan saat ini membuat program off air, program itu dibawa ke off air agar engagement-nya dengan penonton lebih dapat. Kalau CNN Indonesia TV mempunyai lokomotif program yang akan dioptimalkan. 
Trans TV sebagai organisasi entitas hiburan, yang dijual adalah program. Tapi kalau berbicara mengenai entitas pemberitaan, maka yang dijual itu bukan program lagi. Masyarakat itu tidak mengetahui program today, news room, tetapi masyarakat mengetahui CNN Indonesia. Masyarakat tidak mengetahui program selamat pagi Indonesia, talknews di Metro TV, tetapi masyarakat mengetahui Metro TV. Setiap program yang di hadirkan setiap stasiun televisi, masyarakat tidak peduli atau tidak memerhatikan program-programnya melainkan lebih memerhatikan kepada stasiun televisinya.

CNN Indonesia TV melakukan kedua poin tersebut, satunya untuk awareness program dan yang kedua adalah untuk mendefinisikan dirinya di market atau pasar. Mendefinisikan dirinya sebagai entitas pemberitaan yang kredibel. CNNIndonesia.com pada awalnya menjadi standar Internasional apapun yang diharapkan dapat memiliki pasarnya sendiri. Ketika itu dilakukan, maka secara organisasi secara struktur yang dibawa kesana adalah struktur organisasi PR yang ada di Trans TV.

Pada awalnya tujuan dan fungsi Public Relations yang dimiliki CNN Indonesia TV ini sama dengan tujuan dan fungsi PR di Trans TV, seperti:

\section{Corporate and Government Relations}

Menjalin hubungan perusahaan dengan pemerintah guna menciptakan keselarasan antara berbagai kebijakan pemerintah dengan perusahaan (investasi, kerja sama dagang, pajak dll, memberikan jaminan perlindungan disaat krisis dan mempercepat proses birokrasi atas berbagai kepentingan perusahaan), hal yang dilakukan seperti media visit, media partner, dan internal relations.

\section{Media Relations}

Merupakan bentuk strategi komunikasi seorang Public Relations professional dalam menjaga hubungan dengan media. Menjalin dan mempertahankan hubungan baik dengan media amatlah penting bagi seorang Public Relations. Dikarenakan CNN Indonesia TV ini merupakan sebuah media, jadi yang dimaksud fungsi media relations disini kepada media eksternal.

\section{Community Relations}

Upaya membina hubungan harmonis antara perusahaan/organisasi dengan komunitas masyarakat untuk meningkatkan kepedulian sosial dan saling pengertian, seperti membangun komunitas $\mathrm{CNN}$, membuat event off air atau on air, dan mempunyai database komunitas- komunitas.

\section{Event Specialist}

Praktisi Public Relations atau MPR membuat event terkait media partner atau membuat event off air atau on air untuk CNN Indonesia TV. Publicity and Merchandising Graphic Designer

Keenam poin tersebut merupakan tujuan dan fungsi PR di Trans Media yang diadposi oleh CNN Indonesia TV. Pada satu tahun pertama CNN Indonesia TV masih menjalankan hal yang sama dengan Trans TV, namun akhirnya pada tahun 2017, tujuan dan fungsi Public Relations pada MPR CNN Indonesia TV berubah total. Perubahan itu dilakukan karena CNN Indonesia TV melakukan restrukturisasi. Ketika misalnya sebuah perusahaan memiliki program PR, dan perusahaan tersebut memiliki 
struktur yang sama dengan Trans TV untuk menjalankan visinya. Maka yang terjadi adalah biaya yang dikeluarkan oleh PR perusahaan tersebut akan sangat banyak.

Setelah satu atau dua tahun tidak tercapai, CNN Indonesia TV yang terbilang perusahaan baru, maka revenue-nya belum optimal maka pasti biayanya akan membebani. Maka CNN Indonesia TV mencari biaya- biaya yang dianggap kurang penting untuk di pangkas. Sekarang kalau seorang praktisi PR masih menjalankan seperti itu, maka saat perusahaan lagi berada diatas, bisa dengan mudah menghabiskan anggaran. Namun ketika perusahaan sedang berada di bawa, maka sumber- sumber biaya yang tidak penting akan dipotong, kalau biaya program yang dipotong mungkin tidak terlalu bermasalah, tetapi ketika organisasinya di restrukturisasi dan diefisiensikan maka biayanya akan dipangkas. Dan hal itu akan berdampak pada departemen MPR yang akan merasa kesulitan dalam merealisasikan sebuah program untuk kedepannya.

Alasan misi PR di CNN Indonesia TV bisa berkontribusi langsung pada bisnis inti di revenue perusahaan. Karena pada prinsipnya harus susah untuk ditiadakan, CNN Indonesia TV merupakan perusahaan baru maka hal ini akan ditemukan juga di PR perusahaan baru manapun. Menurut Business of Development (BOD), selama 2 tahun merupakan waktu yang cukup. CNN Indonesia TV sudah memiliki entalase di Trans TV di Good Morning dan Viral. Di Trans ada di Redaksi Siang. Menurut Om Fred sebagai Head of Marketing Public Relations Division CNN Indonesia TV, untuk mendapatkan sebuah awareness CNN Indonesia TV sudah mendapatkannya. Kalau perusahaan lain mempunyai visi PR untuk image, tetapi kalau perusahaan media itu visi nya adalah layer, konten berita, positioning PR nya netral atau tidak. Itulah PR perusahaan media, itulah alasannya tugas- tugas seperti mengundang narasumber, publikasi, dan lain-lain bukan beban PR lagi. Jadi tujuan dan fungsi PR di MPR CNN Indonesia TV itu tidak terlalu rumit seperti PR di Trans TV. Tujuan dan fungsi PR nya dirubah, yang tadinya memiliki 6 poin menjadi 2 poin, yaitu partnership specialist dan event specialist.

Pengurangan tujuan dan fungsi PR pada Departemen Marketing PR di CNN Indonesia TV selain atas dasar efisiensi juga selaras dengan misi dari Departemen MPR CNN Indonesia TV yaitu dapat terjun langsung pada pendapatan perusahaan. Walaupun tujuan dan fungsi PR di departemen MPR CNN Indonesia TV ini sudah diperkecil namun secara tugasnya, masih menjalan tugas PR yang lainnya seperti audiensi terhadap pihak eksternal, menerima media visit hingga company visit.

Melihat dari tujuan dan fungsi Public Relations pada departemen marketing public relations di CNN Indonesia terdiri dari partnership specialist dan event specialist. Tentu aktivitas yang dilakukan departemen MPR CNN Indonesia tidak jauh berhubungan dengan pihak eksternal dan juga event. Dengan CNN Indonesia mempunyai 2 fungsi tersebut, maka kedua-duanya ini, menyatakan bahwa kita akan berkontribusi di bisnis inti, maka KPI nya juga yang real. KPI nya duit. Jadi siapa yang akan bekerja sama dengan CNN Indonesia yang akan menghasilkan uang. Programnya berupa event. CNN Indonesia harus bisa menjadi yang pertama dalam melakukan atau menyelenggarakan event tersebut. Event yg diinisiasi oleh CNN Indonesia ada 3:

\section{Monolog}

Monolog ini baru sekali diadakan di CNN Indonesia TV. Dimana konsep event 
ini dengan mendatangkan seorang narasumber yang akan menceritakan bagaimana kisah seseorang tersebut menjalani hidupnya. Jadi yang akan dijual dari event ini adalah story teller. Objectives pada event monolog ini adalah orang- orang yang ingin mendapatkan inspirasi dari cerita seorang tokoh. Sasaran dari event ini adalah mahasiswa, dan cara penyebaran informasi mengenai event ini melalui iklan atau menggunakan media yang tidak mengeluarkan biaya.

Monolog baru pertama kali dilaksanakan dan belum pernah dilaksanakan kembali dikarenakan tidak adanya sponsor. Namun event Monolog ini sedang dirancang untuk diadakan kembali dengan terlebih dahulu mencari perusahaan-perusahaan yang bisa bekerja sama, mempunyai visi dan tujuan yang sama dengan CNN Indonesia TV untuk merealisasikan event monolog ini. Contohnya, monolog mengundang tokoh Melani Sugono. Yang orang lain ketahui bahwa kehidupannya Melani Sugono itu tidak baik, namun pada akhirnya Melani Sugono dapat menemukan titik yang dapat merubah hidupnya. Atau tokoh Aan Mansyur, bagaimana ia dikenal mempunyai masalah pada dirinya. Puisi-puisi yang dibuat Aan Mansyur sudah sangat terkenal, tapi dibalik itu semua ternyata sosok Aan Mansyur adalah seseorang yang susah berkomunikasi dengan orang lain, bahkan ibunya sendiri. Hal ini lah yang di angkay oleh CNN Indonesia dalam event Monolog.

\section{Dialog}

Dialog ini tidak jauh berbeda dengan konsep Monolog, event off air yang dikemas menarik dan mudah dipahami. Event dialog ini lebih mengulas mengenai isu terkini. Ketika terjadi suatu permasalahan, dan CNN Indonesia TV sebagai wadah untuk mengulas permasalahan tersebut sebagai entitas TV berita. Seperti menyiapkan stakeholder, semua opinion leader, influencer terkait isu tersebut dihadirkan dalam satu acara yaitu dialog.

Event Dialog ini akan menjadi wadah untuk mempertemukan titik permasalahan yang valid. Audiens event dialog ini adalah orang-orang yang benar ingin mengetahui kebenaran dari isu terkait. Tujuan dari dibuatnya event dialog ini, diharapkan audiens yang datang pada event dialog ini nantinya dapat memberikan pemahaman yang impact-nya multiplayer.

\section{Meet Up}

Program Meet Up merupakan program yang diadakan oleh MPR CNN Indonesia untuk pertama kalinya. Namun pada awalnya, CNN Indonesia tidak memiliki tujuan spesifik dalam membuat program Meet Up. Berkolaborasi dengan anak- anak kampus, dan CNN Indonesia menjadi sebuah wadah pelaksanaan, sedangkan pihak partner yang akan menyediakan peserta, perizinan tempat, juga tempat yang akan digunakan. Meet Up merupakan program yang memiliki konsep menargetkan kepada generasi milenial atau generasi muda yaitu anak-anak kampus.

Itu menjadi alasan CNN Indonesia TV melanjutkan program Meet Up, apapun agenda didalamnya jurnalistiknya harus tetap ada. Gimana cara CNN Indonesia TV menyiapkan konsumennya untuk masa yang akan datang. Di masa depan, oran yang mengonsumsi program CNN Indonesia itu tidak hanya dari layer TV, melainkan bisa melalui Instagram, You tube, atau darimana saja. Tapi poin pentingnya adalah, CNN Indonesia TV itu pasti kredibel dan bisa dipercaya. Jadi itu adalah ajang CNN Indonesia melakukan promosi di event Meet Up. 
Program Meet Up diadakan kembali, dikarenakan CNN Indonesia Tv bisa masuk ke generasi anak zaman sekarang dengan mengikuti keinginan dan kemauan mereka. KPA program Meet Up ini adalah uang. Evaluasi dari program Meet Up ini dapat dilihat dari 2 sisi, eksternal dan internal. Kalau eksternal melihat dari pihak sponsor, misalnya BkkbN melihat evaluasi program dari numbers (jumlah kehadiran), kalau dari sisi internal melihat dari konten yang diberikan melalui audiens experience. Kegiatan off air lebih mudah dibandingkan on air, uang yang digunakan untuk mengadakan sebuah kegiatan off air yaitu yang bisa di bakar dengan sangat cepat, namun yang penting dalam sehari itu pengalaman audiens dilapangan sesuai dengan tujuannya. Berbeda dengan kegiatan on air, pertama yang dilakukan harus membuat rencana itu naik, namun masih ada kemungkingan rating share nya tidak mencukupi dan akhitnya di evaluasi lagi.

Kegiatan Meet Up ini merupakan kegiatan off air, jadi sehari selesai. Evaluasinya juga melalui observasi saat dilapangan. Dan bagaimana cara CNN Indonesia menyajikan konten yang dapat mem-positioning perserta itu, ada 2 yang menjadi dasar acuan CNN Indonesia membuat kegiatan, yang pertama entrepreunership dan kedua adalah leadership.

CNN Indonesia TV tidak memberikan sponsor kepada pihak eksternal, melainkan memberikan inventory seperti spot promo. Itupun juga melihat dari konten yang ditawarkan apakah berkualitas atau tidak. CNN Indonesia TV tidak dapat memberikan sponsor berupa fresh money. Hal ini hanya dilakukan oleh media CNN Indonesia TV, dan tidak dilakukan oleh perusahaan media lainnya.

Melihat perkembangan teknologi di era sekarang ini, tentu menjadi tanda bahaya bagi para media konvensional. Namun hal ini tidak dirasakan oleh CNN Indonesia TV. Om Fred selaku kepala Marketing Public Relations CNN Indonesia TV menganggap bahwa perubahan itu harus di hadapi. Seperti dari pada sendirian menghadapi perubahan itu, lebih baik mengikuti perubahan yang ada. Dan melihat dari sisi lainnya, seperti melihat adanya peluang yang sangat besar pada perubahan tersebut untuk maju lebih dulu dibandingkan dengan yang lainnya.

Hasil penelitian menggambarkan temuan utama dari penelitian. Sajian dalam hasil dan pembahasan ditulis secara bersistem, hanya hasil data/informasi yang terkait dengan tujuan penelitian. Pembahasan dalam artikel penelitian menjelaskan hasil yang didapat dari penelitian.

Contoh gambar:

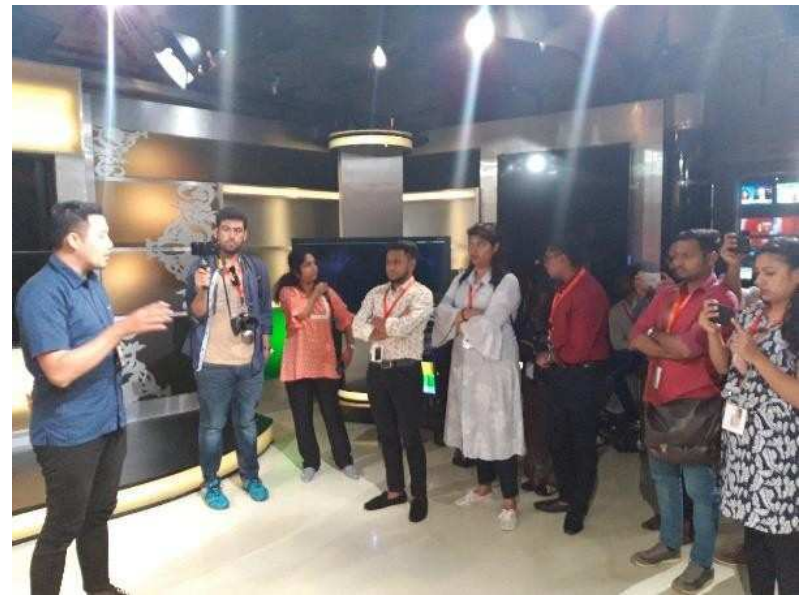




\section{ke Kantor CNN Indonesia}

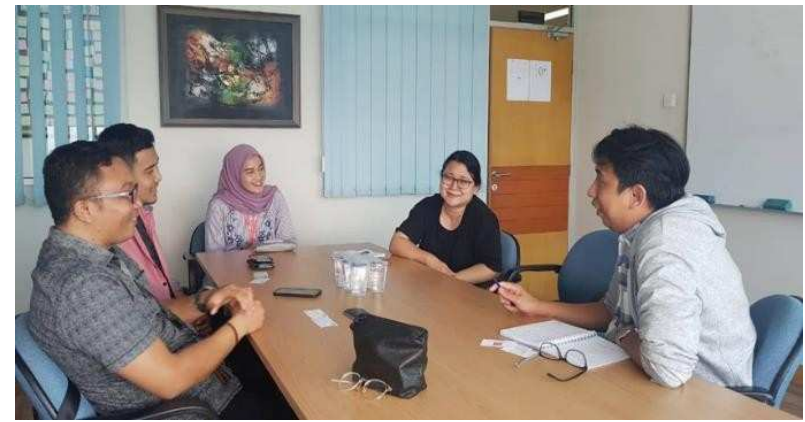

Sumber: Dokumentasi Peneliti, 2018 Gambar 2 Meeting bersama pihak Kampus UNTAR untuk kegiatan Meet Up

\section{KESIMPULAN}

Dari hasil penilitian dapat disimpulkan bahwa CNN Indonesia TV menerapakan manajemen mirroring dalam sistem kerjanya, guna memperdayakan satu orang namun satu orang tersebut dapat dan mampu mengerjakan 2 sampai 3 pekerjaan sekaligus atau multitasking. Hal tersebut dilakukan guna mencapai sebuah tujuan yaitu efisiensi, Tujuan dan fungsi Marketing Public Relations pada CNN Indonesia TV ada 2 yaitu, partnership specialist dan event specialist. Marketing Public Relatios CNN Indonesia TV pada prinsipnya adalah merupakan suatu kegiatan yang terencana dan suatu usaha yang terus menerus untuk dapat memantapkan dan mengembangan itikad baik (good will), namun disisi lain tujuan nya adalah mendapatkan keuntungan sebesar-besarnya di setiap kegiatan yang dilaksanakan dan pada akhirnya dapat berdiri sendiri untuk memenuhi kebutuhan Marketing PR di CNN Indonesia TV, selain itu CNN Indonesia harus bisa menjadi yang pertama dalam melakukan atau menyelenggarakan sebuah event. Event yg diinisiasi oleh CNN Indonesia ada 3, yaitu Monolog, Dialog dan Meet Up. Pandangan CNN Indonesia TV mengenai perkembangan hadirnya new media adalah mengikuti arah perubahan tersebut dan melihat dampak positif juga peluang yang sangat besar pada perubahan tersebut untuk maju lebih dulu dibandingkan dengan yang lainnya. Berdasarkan kesimpulankesimpulan yang telah dipaparkan sebelumnya, peneliti mencoba untuk menawarkan beberapa saran bagi departemen Marketing PR CNN Indonesia TV. Proses Public Relations pada pelaksanaan sebuah kegiatan sudah dijalankan oleh departemen MPR CNN Indonesia TV, namun selama penulis magang di CNN Indonesia TV belum pernah melihat bentuk fisik evaluasi dari setiap kegiatan yang dilakukan oleh departemen MPR CNN Indonesia TV. Alangkah baiknya, bentuk fisik evaluasi secara rinci pada setiap kegiatan yang dilakukan oleh departemen MPR tetap dilakukan sehingga akan lebih mudah melihat hasil evaluasi untuk mengadakan kegiatan selanjutnya. Selain itu juga kegiatan on air pada CNN Indonesia TV tentu tidak perlu diragukan lagi, karena CNN Indonesia TV merupakan media pemberi informasi yang aktual juga tepercaya. Namun yang peneliti ketahui, bahwa kegiatan CNN Indonesia TV akan bisa terlaksana apabila mendapatkan sponsor, dan harapan peneliti untuk 
kedepannya CNN Indonesia TV dapat merealisasikan sebuah kegiatan tanpa adanya sponsor dan juga meluaskan target dari publiknya.

\section{DAFTAR PUSTAKA}

Abdurrachman,Oemi. (2001). Dasar-Dasar Public Relations. Bandung: PT. Citra Aditya

Bakti.

Almira, Septika Khairunnisa dan Suharyanti. (2014). Journal Communication Spectrum, Vol. 4: Implementasi Strategi Marketing Public Relations Dalam Pengelolaan Citra Merek.

Ardianto, Dr. Elvinaro. (2011). Handbook of Public Relations. Bandung: Simbiosa Rekatama Media.

Danandjaja. (2011). Peranan Humas dalam Perusahaan Yogyakarta. Yogyakarta: Graha Ilmu. Darmastuti, S.Sos., M.Si, Rini.. (2012). Media Relations Konsep, Penerbit Andi.

Strategi \& Aplikasi. Salatiga:

Gregory, Anne. (2005). Public relations dalam Praktik. Jakarta: Erlangga.

Harris, Thomas L. (1991). The Marketer's Guide to Public Relations. United States of America: John Wiley and Sons, Inc.

Jefkins, Frank. (1992). Public Relations (Edisi Keempat). Jakarta: Erlangga.

Silih Agung Wasesa. (2005). Strategi Public Relations.

Jakarta: PT. Gramedia Pustaka Utama.

Yulianita, Hj. Neni. (2001). Dasar-Dasar Public Relations. Bandung: Multimedia, Fikom Unisba. 